\title{
STUDIES ON THE METABOLISM OF BIOTIN VITAMERS BY MICROORGANISMS(Abstract_要旨)
}

$\operatorname{AUTHOR}(S):$

Yang, Han Chul

CITATION:

Yang, Han Chul. STUDIES ON THE METABOLISM OF BIOTIN VITAMERS BY MICROORGANISMS. 京都大学, 1971, 農学博士

ISSUE DATE:

1971-05-24

URL:

http://hdl.handle.net/2433/213662

RIGHT: 


\section{【249】}

氏 名

学位 の種類

学位記番号

学位授与の日付

学位授与の要件

研究科・専攻

学位論文題目

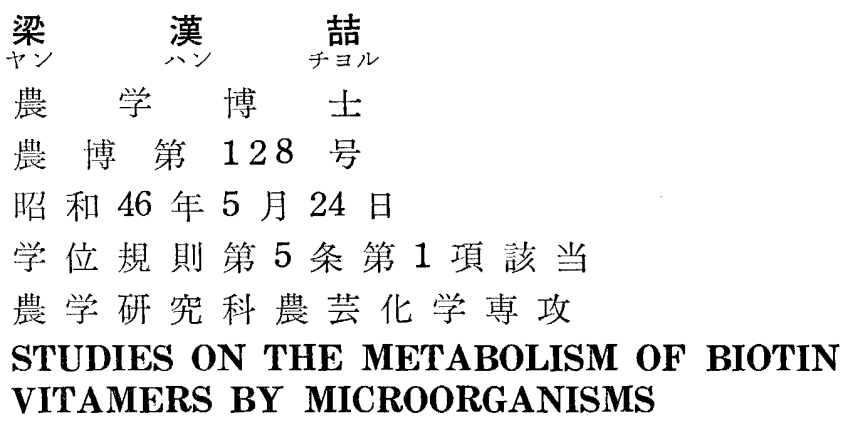

（微生物によるビオチン活性物質の代謝に関する研究）

(主 查)

論文調查委員教授緒方浩一教授満田久輝教授栃倉辰六郎

\section{論文内容の要旨}

本論文は biotin 扔よび biotin 活性物質の微生物による代謝抢よび生合成経路解明の一環として ureido 環形成機構を検討した結果を取りまとめたものでめる。

Biotin を含む培地に各種の微生物を培養したところ biotin を代謝分解する微生物が多数存在すること

(第 1 図)

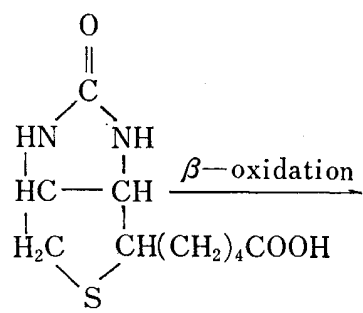

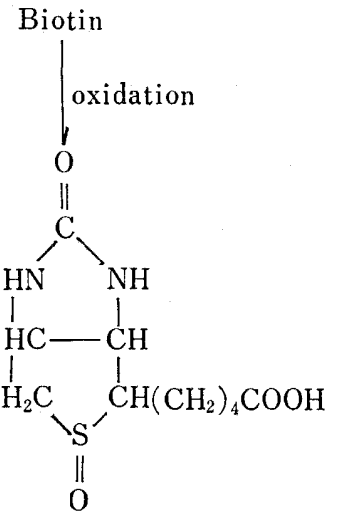

Biotin sulfoxide<smiles>O=C(O)CC1SCC2CCCC1NC2=O</smiles>

Bisnorbiotin oxidation<smiles>O=C(O)CC1CS(=O)C2CC1NC2=O</smiles>

Binorbiotin sulfoxide 
を認めた。特にその作用の顕著な Endomycopsis 属执よび Rhodotorula 属酵母を用いて biotin の代謝 産物を単離しその化学的性質を明らかにしたところ bisnorbiotin, bisnorbiotin sulfoxide, biotin sulfoxide であった。これらの菌では biotin sulfoxide から bisnorbiotin sulfoxide へ転換する系は認められなか ったので，著者は第 1 図に示すように biotin はまず $\beta$-酸化によって bisnorbiotin となり，さらに酸化 されて bisnorbiotin sulfoxide となり，また一方 biotin の一部は直接酸化されて biotin sulfoxide とな ると結論した。

さらに従来 biotin 生合成系の中間体と認められていなかった biotin diaminocarboxylic acid から Bacillus sphaericus, Rhodotorula rubra などの休止菌体によって biotin が生合成され，Rhodotorula の 場合は生成した biotin は bisnorbiotin へ $\beta$-酸化されることを見いだした。（第 2 図）

（第 2 図）

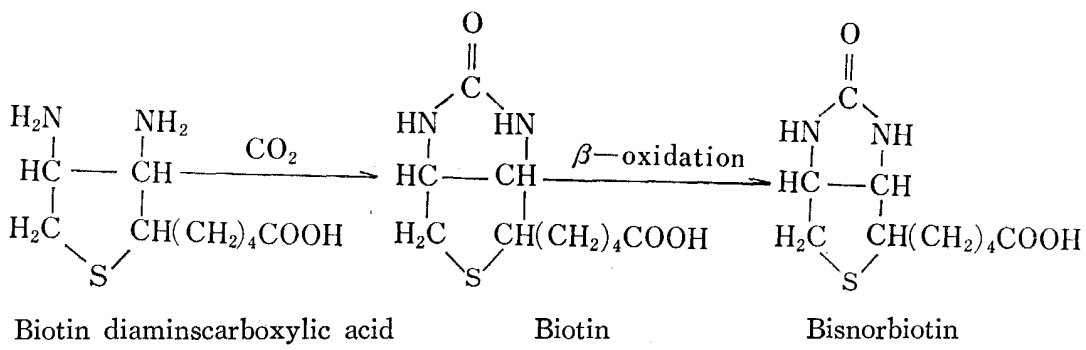

また biotin 生合成の中間体と認められている 7,8-diaminopelargonic acid からは Rhodotorula 属䤉 母などによって desthiobiotin 拉よびその $\beta$ 酸化物である bisnordesthiobiotin が生成することを認めた。

（第 3 図）

（第 3 図）

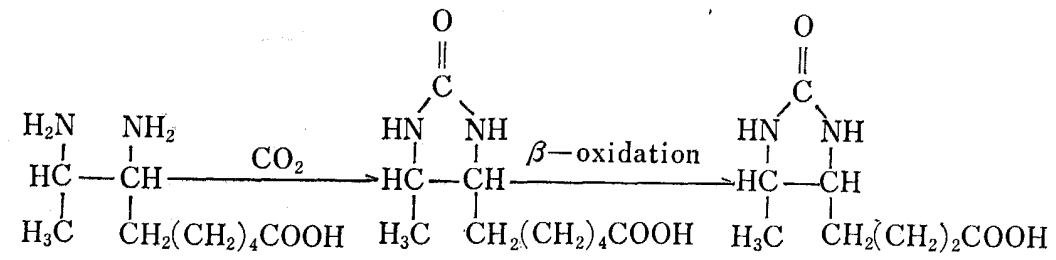

7,8-Diaminocarboxylic acid Desthiobiotin Bisnordesthiobiotin

これらの反応に関与する ureido 環形成酵素をPseudomonas graveolens の菌体より抽出し, 粗抽出液 に対して 2,000 倍の比活性を示すほとんど単一たんぱく質よりなる標品をえた。その酵素化学的諸性質を 検討し, 炭酸基供与体として $\mathrm{NaHCO}_{3}$ が有効であり, 補酵素として $\mathrm{ATP}$, さらに $\mathrm{Mg}^{2+}$ を要求するこ とを明らかにした。また本酵素の特異性は 7,8-diaminoperalgonic acid に対して活性が高く, biotin diaminocarboxylic acid に対してはその1/10の活性を示し，その他の pelargocic acid 系物質には作用しな かった。 


\section{論 文審 查の結 果の要旨}

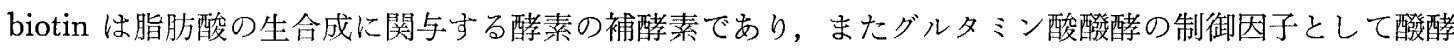
工業上からも重要なビタミンである。しかし微生物による biotin 活性物質の代謝については不明な点が 多い。

著者はまず biotin を含む培地に多くの微生物を培養し, biotin を分解する微生物が多数存在すること を知り，その分解物を単離同定した。

それらの物質の中で bisnorbiotin, bisnorbiotin sulfoxide は著者がはじめて見いだし命名したものであ るが, さらに biotin sulfoxideをも単離した。著者が使用した Endomycopsis 属酵母では biotin sulfoxide から bisnorbiotin sulfoxideへの酸化系は存在しなかった。したがって本菌では biotin はまず 眰化によって bisnorbiotin となり，さらに酸化されて bisnorbiotin sulfoxide となる系の存在を指摘 した。

さらに従来 biotin の生合成の中間体としては認められていなかった biotin diaminocarboxylic acid から biotin が生成すること招よび 7,8-diaminocarboxylic acid から desthiobiotin が生成することを多 くの微生物で認めた。この反応に関与する ureido 環形成䤉素をPseudomonas graveolens の菌体より抽 出し，ほとんど単一たんぱく質となるまで精製し酵素化学的性質を検討した。本酵素による ureido 環の 形成には炭酸基供与体として， $\mathrm{NaHCO}_{3}$ が有効であり，また補酵素として ATP，さらに $\mathrm{Mg}^{2+}$ が必要 であることを明らかにした。

以上の成果は biotin の微生物による代謝に関して新しい知見を加えたものでビタミン学, 微生物生理 学に貢献するところが大きい。

よって，本論文は農学博士の学位論文として価値あるものと認める。 